\title{
PRINSIP DAN ALAT EVALUASI DALAM PENDIDIKAN ISLAM
}

\author{
Muh. Haris Zubaidillah \\ Email: bariszub@gmail.com
}

\begin{abstract}
Abstrak
Proses pembelajaran dengan mengaplikasikan berbagai model-model pembelajaran yang bertujuan untuk meningkatkan minat, motivasi, aktivitas, dan hasil belajar. Hasil belajar siswa dapat diketahui meningkat atau rendah setelah dilaksanakan sebuah evaluasi. Proses evaluasi meliputi pengukuran dan penilaian. Pengukuran bersifat kuantitatif sedangkan penilaian bersifat kualitatif. Proses evaluasi bukan sekedar mengukur sejauh mana tujuan tercapai, tetapi digunakan untuk membuat keputusan. Keputusan dan pendapat akan dipengaruhi oleh kesan pribadi dari yang membuat keputusan. Prinsip-prinsip evaluasi yaitu komprehensif, komparatif, kontinyu, obyektif, criteria yang valid, fungsional, diagnostik, keterpaduan, keterlibatan peserta didik, koherensi, pedagogis, dan akuntabel. Jenis-jenis alat evaluasi yaitu tes berupa (tes awal, tes akhir, tes seleksi, tes diagnostik, tes formatif, tes sumatif, tes intelegensi, tes kemampuan, tes kepribadian, tes hasil belajar, tes sikap, tes individual, tes kelompok, power tes, speed tes, verbal tes, nonverbal tes, tes tertulis, dan tes lisan) dan nontes berupa (Skala bertingkat (rating scale), Kuesioner, Daftar cocok (chek list), Wawancara (interview), Pengamatan (observasi)).
\end{abstract}

Kata Kunci: prinsip, alat, evaluasi, pendidikan islam

\section{A. PENDAHULUAN}

Proses pembelajaran dengan mengaplikasikan berbagai model-model pembelajaran yang bertujuan untuk meningkatkan minat, motivasi, aktivitas, dan hasil belajar. Hasil belajar siswa dapat diketahui meningkat atau rendah setelah dilaksanakan sebuah evaluasi. Proses evaluasi meliputi pengukuran dan penilaian. Pengukuran bersifat kuantitatif sedangkan penilaian bersifat kualitatif. Proses evaluasi bukan sekedar mengukur sejauh mana tujuan tercapai, tetapi digunakan untuk membuat keputusan. Keputusan dan pendapat akan dipengaruhi oleh kesan pribadi dari yang membuat keputusan.

Pengukuran dalam bidang pendidikan erat kaitannya dengan tes. Hal ini dikarenakan salah satu cara yang sering dipakai untuk mengukur hasil yang telah dicapai siswa adalah dengan tes. Penilaian merupakan bagian penting dan tak terpisahkan dalam sistem pendidikan saat ini. Peningkatan kualitas pendidikan dapat dilihat dari nilai-nilai yang diperoleh siswa. Tentu saja untuk itu diperlukan sistem penilaian yang baik dan tidak bias. Sistem penilaian yang baik akan mampu 
memberikan gambaran tentang kualitas pembelajaran sehingga pada gilirannya akan mampu membantu guru merencanakan strategi pembelajaran. Bagi siswa sendiri, sistem penilaian yang baik akan mampu memberikan motivasi untuk selalu meningkatkan kemampuannya. Oleh karena itu, penulis membahas dalam makalah ini mengenai prinsip dan alat evaluasi.

\section{B. PRINSIP-PRINSIP EVALUASI}

Untuk memperoleh hasil evaluasi yang lebih baik, maka kegiatan evaluasi harus bertitik dari prinsip-prinsip umum sebagai berikut:

1. Kontinuitas

Evaluasi tidak boleh dilakukan secara insedental karena pembelajaran itu sendiri adalah suatu proses yang kontinyu. Oleh sebab itu evaluasi pun harus dilakukan secara kontinyu pula.

2. Komprehensif

Dalam melakukan evaluasi terhadap suatu obyek, guru harus mengambil seluruh obyek itu sebagai bahan evaluasi.

3. Adil dan obyektif

Dalam melaksanakan evaluasi guru harus berlaku adil dan tanpa pilih kasih kepada semua peserta didik. Guru juga hendaknya bertindak secara obyektif, apa adanya sesuai dengan kemampuan peserta didik.

4. Kooperatif

Dalam kegiatan evaluasi hendaknya guru bekerjasama dengan semua pihak, seperti orang tua peserta didik, sesama guru, kepala sekolah, termasuk dengan peserta didk itu sendiri.

5. Praktis

Praktis mengandung arti mudah digunakan baik oleh guru itu sendiri yang menyusun alat evaluasi maupun orang lain yang akan menggunakan alat tersebut. ${ }^{1}$

Menurut Khusnuridlo ${ }^{2}$, prinsip-prinsip evaluasi terdiri dari :

1. Komprehensif

Evaluasi harus mencakup bidang sasaran yang luas atau menye $\neg$ luruh, baik aspek personalnya, materialnya, maupun aspek operasionalnya. Evaluasi tidak hanya ditujukan pada salah satu aspek saja. Misalnya aspek personalnya, jangan hanya menilai gurunya saja, tetapi juga murid, karyawan dan kepala sekolahnya. Begitu

${ }^{1}$ Dian Ramadani (2012), Prinsip dan Alat Evaluasi, dianramadani150393.blogspot. co.id, diakses pada 25 Maret 2016

2 Khusnuridlo. (2010). Prinsip-prinsip Evaluasi Program Supervisi Pendidikan (Online). (http://www.khusnuridlo.com, diakses 25 Maret 2016 
pula untuk aspek material dan operasionalnya. Evaluasi harus dilakukan secara menyeluruh.

2. Komparatif

Prinsip ini menyatakan bahwa dalam mengadakan evaluasi harus dilaksa-nakan secara bekerjasama dengan semua orang. Sebagai contoh dalam mengevaluasi keberhasilan guru dalam mengajar, harus bekerjasama antara pengawas, kepala sekolah, guru itu sendiri, dan bahkan, dengan pihak murid. Dengan melibatkan semua pihak diharapkan dapat mencapai keobyektifan dalam mengevaluasi.

3. Kontinyu

Evaluasi hendaknya dilakukan secara terus-menerus selama proses pelaksanaan program. Evaluasi tidak hanya dilakukan terhadap hasil yang telah dicapai, tetapi sejak pembuatan rencana sampai dengan tahap laporan. Hal ini penting dimaksudkan untuk selalu dapat memonitor setiap saat atas keberhasilan yang telah dicapai dalam periode waktu tertentu. Aktivitas yang berhasil diusahakan terjadi peningkatan, sedangkan aktivi-tas yang gagal dicari jalan lain untuk mencapai keberhasilan.

4. Obyektif

Mengadakan evaluasi harus menilai sesuai dengan kenya $\neg$ taan yang ada. Katakanlah yang hijau itu hijau dan yang merah itu merah. Jangan sampai mengatakan yang hijau itu kuning, dan yang kuning itu hijau. Sebagai contoh, apabila seorang guru itu sukses dalam mengajar, maka katakanlah bahwa guru ini sukses, dan sebaliknya apabila jika guru itu kurang berhasil dalam mengajar, maka katakanlah bahwa guru itu kurang berhasil. Untuk mencapai keobyektifan dalam evaluasi perlu adanya data dan fakta. Dari data dan fakta inilah dapat mengolah untuk kemudian diambil suatu kesimpulan. Makin lengkap data dan fakta yang dapat dikumpulkan maka makin obyektiflah evaluasi yang dilakukan.

5. Berdasarkan Kriteria yang Valid

Selain perlu adanya data dan fakta, juga perlu adanya kriteria-kriteria tertentu. Kriteria yang digunakan dalam evaluasi harus konsisten dengan tujuan yang telah dirumuskan. Kriteria ini digunakan agar memiliki standar yang jelas apabila menilai suatu aktivitas supervisi pendi $\neg$ dikan. Kekonsistenan kriteria evaluasi dengan tujuan berarti kriteria yang dibuat $\urcorner$ harus mempertimbangkan hakikat substansi supervisi pendidikan.

6. Fungsional

Evaluasi memiliki nilai guna baik secara langsung maupun tidak langsung. Kegunaan langsungnya adalah dapatnya $\neg$ hasil evaluasi digunakan untuk perbaikan apa yang dievaluasi, sedangkan kegunaan tidak langsungnya adalah hasil evaluasi itu dimanfaatkan untuk penelitian atau keperluan lainnya.

7. Diagnostik 
Setiap hasil evaluasi harus didokumentasikan. Bahan-bahan dokumentasi hasil evaluasi inilah yang dapat dijadikan dasar penemuan kelemahan-kelemahan atau kekurangan-kekurangan yang kemudian harus diusahakan jalan pemecahannya.

Menurut Yunanda, prinsip-prinsip evaluasi yaitu ${ }^{3}$ :

1. Keterpaduan

Evaluasi harus dilakukan dengan prinsip keterpaduan antara tujuan intruksional pengajaran, materi pembelajaran, dan metode pengajaran.

2. Keterlibatan peserta didik

Prinsip ini merupakan suatu hal yang mutlak, karena keterlibatan peserta didik dalam evaluasi bukan alternative, tapi kebutuhan mutlak.

3. Koherensi

Evaluasi harus berkaitan dengan materi pengajaran yang telah dipelajari dan sesuai dengan ranah kemampuan peserta didik yang hendak diukur.

4. Pedagogis

Aspek pedagogis diperlukan untuk melihat perubahan sikap dan perilaku sehingga pada akhirnya hasil evaluasi mampu menjadi motivator bagi diri siswa.

5. Akuntabel

Hasil evaluasi haruslah menjadi alat akuntabilitas atau bahan pertanggungjawaban bagi pihak yang berkepentingan seperti orangtua, siswa, sekolah, dan lainnya.

Menurut Arikunto, prinsip evaluasi merupakan triagulasi yang meliputi tujuan pembelajaran, kegiatan pembelajaran atau KBM, dan evaluasi. ${ }^{4}$

a. Hubungan anatara tujuan dengan KBM

Kegiatan belajar mengajar yang dirancang dalam bentuk rencana mengajar disusun oleh guru dengan mengacu pada tujuan yang hendak dicapai. Dengan demikian, anak panah yang menunjukkan hubungan anatara keduanay mengarah pada tujuan dengan makana bahwa KBM mengacu pada tujuan, tetapi juga mengarah dari tujuan ke KBM, menunjukkan langkah dari tujuan dilanjutkan pemikirannya ke KBM. b. Hubungan tujuan dengan evaluasi, dan

Evaluasi adalah kegiatan pengumpulan data untuk mengukur sejauh mana tujuan sudah tercapai. Dalam menyusun alat evaluasi perlu mengacu pada tujuan yang sudah dirumuskan

c. Hubungan anatara KBM dengan evaluasi

${ }^{3}$ Yunanda, Martha. (2010). Prinsip dan teknik evaluasi. Diakses tanggal 25 maret 2016 dari http://id.shvoong.com/ 25

${ }^{4}$ Arikunto, S. 2005. Dasar-dasar Evaluasi Pendidikan (edisi revisi). Bumi aksara. Jakarta, hal. 24- 
KBM dirancang dan disusun dengan mengacu pada tujuan yang telah dirumuskan, alat evaluasi disusun dengan mengacu pada tujuan, mengacu atau disesuaikan dengan KBM yang dilaksanakan. ${ }^{5}$

Menurut Sudijono, evaluasi hasil belajar dikatakan terlaksan dengan baik apabila dalam pelaksanaannya senantiasa berpegang pada tiga prinsip dasar yaitu: ${ }^{6}$

1. Prinsip keseluruhan

Prinsip keseluruhan dikenal dengan istilah prinsip komprehensif. Prinsip komprehensif dikatakan terlaksana dengan baik apabila evaluasi tersebut dilaksanakan secara bulat, utuh atau menyeluruh. Evaluasi hasil belajar harus dapat mencakup berbagai aspek yang dapat menggambarkan perkembangan atau perubahan tingkah laku yang terjadi pada diri peserta didik sebagai makhluk hidup.

2. Prinsip Kesinambungan

Prinsip kesinambungan dikenal dengan istilah prinsip kontinuitas. Prinsip kontinuitas dimaksudkan bahwa hasil belajar yang baik adalah evaluasi hasil belajar yang dilaksanakan secara teratur dan sambung menyambung dari waktu ke waktu. Evaluasi hasil belajar dilaksanakan secara berkesinambungan agar pihak evaluator dapat memperoleh kepastian dan kemantapan dalam menentukan langkah-langkah atau merumuskan kebijaksanaan untuk masa depan serta memperoleh informasi yang dapat memberikan gambaran mengenai kemajuan atau perkembangan peserta didik.

3. Prinsip obyektivitas

Prinsip objektivitas mengandung makna bahwa evaluasi hasil belajar dapat dinyatakan sebagai evaluasi yang baik apabila dapat terlepas dari factor-faktor yang sifatnya subyektif.

\section{ALAT-ALAT EVALUASI}

Untuk keperluan evaluasi diperlukan alat evaluasi yang bermacam- macam, seperti kuisioner, tes, skala, format observasi, dan lain-lain. Khusus untuk evaluasi hasil pembelajaran alat evaluasi yang paling banyak digunakan adalah tes. Pembahasan evaluasi hasil pembelajaran lebih menekankan pada pemberian nilai terhadap skor hasil tes.

1. Tes

Tes merupakan alat ukur yang standar dan obyektif sehingga dapat digunakan secara meluas untuk mengukur dan membandingkan keadaan psikis atau tingkah laku

5 Kamrianti.Ramli, S.Pd, Prinsip dan Alat Evaluasi, 2011, wwwkamriantiramli85sinjaibiologi.blogspot.co.id, diakses pada 25 Maret 2016 33

${ }^{6}$ Anas Sudijono. (2001). Pengantar Evaluasi pendidikan. Jakarta: Raja Grafindo Persada. Hal. 31 -

7 Hasnawati, Evaluasi Pembelajaran, Stain Sjech M Djamil Djambek Bukittinggi, hal. 40-42. 
individu. Dapat dipastikan akan mampu memberikan informasi yang tepat dan obyektif tentang obyek yang hendak diukur baik berupa psikis maupun tingkah lakunya, sekaligus dapat membandingkan antara seseorang dengan orang lain.

Tes adalah suatu cara atau alat untuk mengadakan penilaian yang berbentuk suatu tugas atau serangkaian tugas yang harus dikerjakan oleh siswa atau sekelompok siswa sehingga menghasilkan nilai tentang tingkah laku atau prestasi siswa tersebut.

Beberapa istilah-istilah yang berhubungan dengan tes ini :

1). Tes

Tes merupakan prosedur yang digunakan untuk mengetahui atau mengukur sesuatu dalam suasana dengan cara dan aturan-aturan yang sudah ditentukan.

2). Testing

Testing merupakan saat pada waktu tes itu dilaksanakan. Dapat juga dikatakan testing adalah saat pengambilan tes.

3). Testee

Testee adalah merupakan responden yang sedang mengerjakan tes.

4). Tester

Tester adalah orang yang melaksanakan pengambilan tes terhadap responden. Dengan kata lain, tester adalah subjek evaluasi (tetapi adakalanya hanya orang yang ditunjuk oleh subjek evaluasi untuk melaksanakan tugasnya). ${ }^{8}$

Sebagai alat evaluasi hasil belajar, tes mempunyai fungsi, yaitu:

a. Untuk mengukur tingkat penguasaan terhadap seperangkat materi atau tingkat pencapaian terhadap seperangkat tujuan tertentu.

b. Untuk menentukan kedudukan atau seperangkat siswa dalam kelompok, tentang penguasaan materi atau pencapaian tujuan pembelajaran. ${ }^{9}$

Tes berdasarkan fungsinya sebagai alat pengukur perkembangan/kemajuan belajar peserta didik yaitu:

\section{Tes seleksi}

Tes seleksi sering dikenal dengan tes saringan atau ujian masuk. Tes ini dilaksanakan dalam rangka penerimaan calon siswa baru, di mana hasil tes digunakan untuk memilih calon peserta didik yang tergolong paling baik dari sekian banyak calon yang mengikuti tes. Tes seleksi merupakan materi prasyarat untuk mengikuti program pendidikan yang akan diikuti oleh calon. Sifatnya yaitu menyeleksi atau melakukan penyaringan.

\section{Tes awal}

8 Anisatul Mahmudah (Student of UIN Sunan Kalijaga Yogyakarta), Makalah Alat Evaluasi Pendidikan, www.perkuliahan.com, diakses pada tanggal 25 Maret 2016 25 Maret 2016

9 Risqi Nafi'atun Nisa', Alat Evaluasi Pendidikan, 2011, risqinisa.wordpress.com diakses pada 
Tes awal dikenal pre-test. Tes awal dilaksanakan dengan tujuan untuk mengetahui sejauh manakah materi atau bahan pelajaran yang akan diajarkan telah dapat dikuasai oleh peserta didik. Isi atau materi tes awal pada umumnya ditekankan pada bahan-bahan penting yang sudah diketahui atau dikuasai oleh peserta didik. Setelah tes awal berakhir, sebagai tindak lanjutnya adalah (a) jika dalam tes awal itu semua materi yang dinyatakan dalam tes sudah dikuasai dengan baik oleh peserta didik, maka materi yang telah dinyatakan dalam tes awal tidak akan diajarkan lagi, dan (b) jika materi yang dapat dipahami oleh peserta didik baru sebagian saja, maka yang diajarkan adalah materi pelajaran yang belum cukup dipahami oleh para peserta didik tersebut .

\section{Tes akhir}

Tes akhir dikenal dengan istilah post-test. Tes akhir dilaksanakan dengan tujuan untuk mengetahui apakah semua materi pelajaran yang tergolong penting sudah dapat dikuasai dengan sebaik-baiknya oleh peserta didik. Isi atau materi tes akhir adalah bahan-bahan pelajaran yang tergolong penting, yang telah diajarkan kepada peserta didik. Jika hasil tes akhir itu lebih baik daripada tes awal maka dapat diartikan bahwa program pengajaran telah berjalan dan berhasil dengan sebaik-baiknya.

\section{Tes Diagnostik}

Tes ini adalah tes yang digunakan untuk mengetahui kelemahan-kelemahan siswa sehingga berdasarkan kelemahan-kelemahan tersebut dapat dilakukan pemberian perlakuan yang tepat. Tes diagnostik juga digunakan untuk mengetahui sebab kegagalan peserta didik dalam belajar, oleh karena itu dalam menyusun butir-butir soal seharusnya menggunakan item yang memiliki tingkat kesukaran rendah.

\section{Tes Formatif}

Tes ini adalah tes untuk mengetahui sejauhmana siswa telah terbentuk setelah mengikuti suatu program tertentu. Tes formatif adalah tes yang digunakan untuk mengetahui atau melihat sejauhmana kemajuan belajar yang telah dicapai oleh siswa dalam suatu program pelajaran.

\section{Tes Sumatif}

Yaitu tes yang dilaksanakan setelah berakhirnya pemberian sekelompok program atau sebuah program yang lebih besar. Tes sumatif ini dapat disamakan dengan ulangan umum yang biasanya dilaksanakan pada tiap akahir semester, catur wulan atau akhir semester. Tes sumatif ini diarahkan kepada tercapai tidaknya tujuantujuan intruksional umum. ${ }^{10}$

Menurut Sudijono tes berdasarkan aspek psikis yang ingin diungkap dibedakan menjadi lima golongan, yaitu: ${ }^{11}$

\footnotetext{
${ }^{10}$ Kamrianti.Ramli, S.Pd, Prinsip dan Alat Evaluasi

11 Anas Sudijono. (2001). Pengantar Evaluasi pendidikan hal. 73
} 
a. Tes intelengensi yakni tes yang dilaksanakan dengan tujuan untuk mengungkap atau mengetahui tingkat kecerdasan seseorang,

b. Tes kemampuan yaitu tes yang dilaksanakan dengan tujuan untuk mengungkap kemampuan dasar atau bakat khusus yang dimiliki testee

c. Tes sikap yaitu salah satu jenis tes yang dipergunakan untuk mengungkap predisposisi atau kecendrungan seseorang untuk melakukan suatu respon tertentu terhadap dunia sekitarnya, baik berupa individu-individu maupun obyek-obyek tertentu.

d. Tes keperibadian yakni tes yang dilaksanakan dengan tujuan mengungkap cirri-ciri khas dari seseorang yang banyak sedikitnya besifat lahiriah, seperti gaya bicara, cara berpakaian, nada suara, hobi atau kesenangan, dan lain-lain.

e. Tes hasil belajar, yang juga sering dikenal dengan istilah tes percapaian yakni tes yang biasa digunakan untuk mengungkap tingkat pencapaian atau prestasi belajar. Tes hasil belajar atau tes prestasi belajar dapat didefinisikan sebagai cara (yang dapat dipergunakan) atau prosedur (yang dapat ditempuh) dalam rangka pengukuran dan penilaian hasil belajar, yang terbentuk tugas dan serangkaian tugas (baik berupa pertanyaan-pertanyaan atau soal-soal) yang harus dijawab, atau perintah-perintah yang harus dikerjakan oleh testee, sehingga (berdasar atas data yang diperoleh dari kegiatan pengukuran itu) dapat menghasilkan nilai yang melambankan tingkah laku atau prestasi belajar testee; nilai mana dapat dibandingkan dengan nilai-nilai standar tertentu, atau dapat pula dibandingkan dengan nilai-nilai yang berhasil dicapai oleh testee lainnya.

Dilihat dari segi banyaknya orang yang mengikuti tes, tes dapat dibedakan menjadi dua golongan, yaitu:

1) Tes individual yakni tes dimana tester berhadapan dengan satu orang testee saja, dan

2) Tes kelompok yakni tes dimana tester berhadapan lebih dari satu orang testee.

Dilihat dari segi waktu yang disediakan bagi testee utuk menyelesaikan tes, tes dapat dapat dibedakan menjadi dua golongan, yaitu:

1) Power test yakni tes di mana waktu yang disediakan buat testee untuk menyelesaikan tes tersebut tidak dibatasi,

2) Speed test yaitu tes di mana waktu yang disediakan buat testee untuk menyelesaikan tes tersebut dibatasi.

Dilihat dari segi bentuk responnya, tes dapat dibedakan menjadi dua golongan, yaitu:

1) Verbal test yakni suatu tes yang menghendaki respon (jawaban) yang tertuang dalam bentuk ungkapan kata-kata atau kalimat, baik secara lisan maupun secara tertulis, dan 
2) Nonverbal test yakni tes yang menghendaki respon (jawaban) dari testee bukan berupa ungkapan kata-kata atau kalimat, melainkan berupa tindakan atau tingkah laku, jadi respon yang dikehendaki muncul dari testee adalah berupa perbuatan atau gerakan-gerakan tertentu.

Ditinjau dari segi cara mengajukan pertanyaan dan cara memberikan jawabannya, tes dapat dibedakan menjadi dua golongan, yaitu:

1) Tes tertulis yakni jenis tes di mana tester dalam mengajukan butir-butir pertanyaan atau soalnya dilakukan secara tertulis dan testee memberikan jawabannya juga secara tertulis, dan

2) tes lisan yakni tes di mana tester di dalam mengajukan pertanyaan-pertanyaan atau soalnya dilakukan secara lisan dan testee memberikan jawabannya secara lisan pula. $^{12}$

Dengan mempertimbangkan kriteria- kriteria dapat dihasilkan alat tes ( soalsoal ) yang berkualitas memenuhi syarat- syarat diantaranya:

- Shahih ( valid) yaitu mengukur yang harus diukur, sesuai dengan tujuan.

- Relevan yaitu diuji sesuai dengan tujuan yang diinginkan.

- Spesifik, soal hanya dapat dijawab oleh peserta didik.

- Representif, soal mewakili materi ajar secara keseluruhan.

Sebuah tes yang bisa dikatakan baik sebagai alat pengukur harus memenuhi persyaratan tes, yaitu memiliki :

a. Validitas

Sebuah tes disebut valid apabila tes tersebut dapat tepat mengukur apa yang hendak diukur. Contoh, untuk mengukur partisipasi siswa dalam proses belajar mengajar, bukan diukur melalui nilai yang diperoleh pada waktu ulangan, tetapi dilihat melalui: kehadiran, terpusatnya perhatian pada pelajaran, ketepatan menjawab pertanyaan-pertanyaan yang diajukan oleh guru dalam arti relevan pada permasalahannya.

b. Reliabilitas

Berasal dari kata asal reliable yang artinya dapat dipercaya. Tes dapat dikatakan dapat dipercaya jika memberikan hasil yang tetap apabila diteskan berkali-kali. Sebuah tes dikatakan reliabel apabila hasil-hasil tes tersebut menunjukan ketetapan. Jika dihubungkan dengan validitas, maka: Validitas adalah ketepatan dan reliabilitas adalah ketetapan.

c. Objektivitas

Sebuah dikatakan memiliki objektivitas apabila dalam melaksanakan tes itu tidak ada faktor subjektif yang mempengaruhi. hal ini terutama terjadipada sistem scoringnya. Apabila dikaitkan dengan reliabilitas maka objektivitas menekankan

${ }^{12}$ Hasnawati, Evaluasi Pembelajaran. hal 90-93 
ketetapan pada sistem scoringnya, sedangkan reliabilitas menekankan ketetapan dalam hasil tes.

d. Prakitikabilitas

Sebuah tes dikatakan memiliki praktibilitas yang tinggi apabila tes tersebut bersifat praktis dan mudah pengadministrasiannya. tes yang baik adalah yang: mudah dilaksanakan, mudah pemeriksaannya, dan dilengkapi dengan petunjuk-petunjuk yang jelas.

\section{e. Ekonomis}

Yang dimaksud ekonomis disini ialah bahwa pelaksanaan tes tersebut tidak membutuhkan ongkos atau biaya yang mahal, tenaga yang banyak, dan waktu yang lama.

\section{Teknik Nonte ${ }^{13}$}

Teknik nontes sangat penting dalam mengevaluasi siswa pada ranah afektif dan psikomotor, berbeda dengan teknik tes yang lebih menekankan asfek kognitif. Teknik penilaian nontes berarti melaksanakan penilaian dengan tidak mengunakan tes. Tehnik peniaian ini umunya untuk menilai keperibadian anak secara menyeluruh meliputi sikap, tingkah laku, sifat, sosial, ucapan, riwayat hidup dan lain-lain yang berhubungan dengan kegiatan belajar dalam pendidkan baik individual maupun secara kelompok.

Yang tergolong teknik non tes adalah

a. Skala bertingkat (rating scale)

Skala yang menggambarkan suatu nilai yang berbentuk angka terhadap suatu hasil perkembangan.

Contoh : kecenderungan seseorang terhadap jenis kesenian tertentu.

b. Kuesioner

Kuesioner juga sering dkenal dengan nama angket. Pada dasarnya, kuesioner adalah berupa daftar pertanyaan yang harus diisi oleh seseorang yang akan diukur (responden). Adapun macam-macam kuesioner dapat ditinjau dari beberapa segi, di antaranya :

1) Ditinjau dari segi persiapan

a) Kuesioner langsung : dikatakan langsung jika kuesioner tersebut dikirimkan dan diisi langsung oleh orang yang akan dimintai jawaban tentang dirinya.

b) Kuesioner tak langsung : adalah kuesioner yang dikirimkan dan diisi oleh bukan orang yang dimintai keterangannya.

2) Ditinjau dari segi cara menjawab

a) Kuesioner tertutup : adalah kuesioner yang disusun dengan menyediakan pilihan jawaban lengkap sehingga pengisi hanya tinggal memberi tanda pada jawaban yang dipilih.

${ }^{13}$ Risqi Nafi'atun Nisa', Alat Evaluasi Pendidikan. 
b) Kuesioner terbuka : adalah kuesioner yang disusun sedemikian rupa sehingga para pengisi bebas mengemukakan pendapatnya.

c. Daftar cocok (chek list)

Adalah deretan pernyataan (yang biasanya singkat), dimana responden yang dievaluasi tinggal membubuhkan tanda $\operatorname{cocok}(\sqrt{ })$ di tempat yang sudah disediakan.

d. Wawancara (interview)

Adalah suatu metode atau cara yang digunakan untuk mendapatkan jawaban dari responden dengan jalan tanya jawab sepihak. Wawancara dapat dilakukan dengan dua cara, yaitu :

1) Interview bebas, dimana responden mempunyai kebebasan untuk mengutarakan pendapatnya tanpa dibataasi oleh patokan-patokan yang telah dibuat oleh subyek evaluasi.

2) Interview terpimpin, yaitu interview yang dilakukan oleh subyek evaluasi dengan cara mengajukan pertanyaan-pertanyaan yang sudah disusun terlebih dahulu.

e. Pengamatan (observasi)

Adalah suatu teknik yang dilakukan dengan cara mengadakan pengamatan secara teliiti serta pencatatan secara sistematis. Ada tiga macam ovservasi yaitu,

1. Observasi partisipan yaitu observasi yang dilakukan oleh pengamat, tetapi dalam pada itu pengamat memasuki dan mengikuti kegiatan kelompok yang sedang diamati. Observasi partisipan dilaksanakan sepenuhnya jika pengamat betul-betul mengikuti kegiatan kelompok, bukan hanya pura-pura. Dengan demikian, ia dapat menghayati dan merasakan seperti apa yang dirasakan orang-orang dalam kelompok yang diamati.

2. Observasi sistematik yaitu di mana faktor-faktor yang diamati sudah didaftar secara sistematis dan sudah diatur menurut kategorinya. Berbeda dengan observasi partisipan, maka dalam observasi sistematik ini pengamat berada di luar kelompok. Dengan demikian maka pengamat tidak dibingungkan oleh situasi yang melingkungi dirinya.

3. Observasi eksperimental terjadi jika pengamat tidak berpartisipasi dalam kelompok. Dalam hal ini ia dapat mengendalikan unsur-unsur penting dalam situasi sedemikian rupa sehingga situasi itu dapat diatur sesuai dengan tujuan evaluasi. ${ }^{14}$

Pengamatan atau observasi sebagai alat atau teknik evaluasi harus memiliki sifat-sifat tertentu yaitu :

1. harus dilakukan sesuai dengan tujuan pengajaran yang telah dirumuskan.

2. Direncanakan secara sistematis.

3. Hasilnya dicatat dan diolah sesuai dengan tujuan.

${ }^{14}$ Dian Ramadani, Prinsip dan Alat Evaluasi, 
4. Dapat diperiksa validitas, reliabilitas dan ketelitiannya. ${ }^{15}$

f. Riwayat hidup

Adalah gambaran tentang keadaan seseorang selama dalam masa kehidupannya. Dengan mempelajari riwayat hidup maka subyek evaluasi akan dapat menarik suatu kesimpulan tentang kepribadian, kebiasaan, dan sikap dari obyek yang dinilai.

Selain teknik-teknik di atas, ada juga teknik lain yaitu :

1) Studi kasus (Case Study)

Adalah studi yang mendalam dan konprehensif tentang peserta didik, kelas atau sekolah yang memiliki kasus tertentu.

2) Catatan insidental (anectodal recored)

Adalah catatan-catatan singkat tentang peristiwa sepintas yang dialami peserta didik secara perorangan.

3) Sosiometri

Adalah suatu prosedur untuk merangkum, menyusun dan sampai batas tertentu dapat mengkuantifikasi pendapat-pendapt peserta didik tentang penerimaan teman sebayanya serta hubungan di antara mereka.

4) Inventori kepribadian

Hampir serupa dengan tes kepribadian. Bedanya dalam inventori kepribadian jawaban peserta didik tidak mempunyai kriteria benar atau salah. Semua jawaban peserta didik adalah benar selama dia menyatakan yang sesungguhnya.

\section{KESIMPULAN}

Prinsip-prinsip evaluasi yaitu komprehensif, komparatif, kontinyu, obyektif, criteria yang valid, fungsional, diagnostik, keterpaduan, keterlibatan peserta didik, koherensi, pedagogis, dan akuntabel.

Jenis-jenis alat evaluasi yaitu tes berupa (tes awal, tes akhir, tes seleksi, tes diagnostik, tes formatif, tes sumatif, tes intelegensi, tes kemampuan, tes kepribadian, tes hasil belajar, tes sikap, tes individual, tes kelompok, power tes, speed tes, verbal tes, nonverbal tes, tes tertulis, dan tes lisan) dan nontes berupa (Skala bertingkat (rating scale), Kuesioner, Daftar cocok (chek list), Wawancara (interview), Pengamatan (observasi))

Penulis mengharapkan kritik dan saran dari pembaca mengenai makalah ini. Karena penulis menyadari adanya kekurangan dalam pembuatan makalah ini.

${ }^{15}$ Slameto, Evaluasi Pendidikan, Bumi Aksara: Jakarta, hal 93-94 


\section{DAFTAR PUSTAKA}

Anisatul Mahmudah (Student of UIN Sunan Kalijaga Yogyakarta), Makalah Alat Evaluasi Pendidikan, www.perkuliahan.com, diakses pada tanggal 25 Maret 2016

Arif, Zaenal. (2010). Evaluasi Pembelajaran Prinsip, Teknik, Prosedur. Bandung: PT Remaja Rosdakarya

Arikunto, S. 2005. Dasar-dasar Evaluasi Pendidikan (edisi revisi). Bumi aksara. Jakarta

Bastable, Susan B. (2002). Perawat Sebagai Pendidik. Jakarta: EGC

Djaali \& Mulyono, Pudji. (2007). Pengukuran dalam Bidang Pendidikan. Jakarta: Grasindo

Hasnawati, Evaluasi Pembelajaran, Stain Sjech M Djamil Djambek Bukittinggi

Hilman. (2010). Pengertian Fungsi dan Prosedur Evaluasi Pembelajaran. Diakses tanggal 23 Februari 2011 dari http://www.hilman.web.id/

Kamrianti. Ramli, S.Pd, Prinsip dan Alat Evaluasi, 2011, wwwkamriantiramli85sinjaibiologi.blogspot.co.id, diakses pada 25 Maret 2016

Khusnuridlo. (2010). Prinsip-prinsip Evaluasi Program Supervisi Pendidikan (Online). (http://www.khusnuridlo.com, diakses 25 Maret 2016

Masidjo, Ign. (1995). Penilaian Hasil Belajar Siswa Di Sekolah. Yogjakarta: Kanisius.

Purwanti, Endang. (2008). Asesmen Pembelajaran SD. Direktoral Jendral Pendidikan Tinggi Departemen Pendidikan Nasional.

Ramadani, Dian (2012), Prinsip dan Alat Evaluasi, dianramadani150393.blogspot. co.id, diakses pada 25 Maret 2016

Risqi, Nafi'atun Nisa', Alat Evaluasi Pendidikan, 2011, risqinisa.wordpress.com diakses pada 25 Maret 2016

Sanjaya, Wina. 2008. Kurikulum dan Pembelajaran. Bandung: Kencana Prenada Media Group.

Slameto, Evaluasi Pendidikan, Bumi Aksara: Jakarta

Sudijono, Anas. (2001). Pengantar Evaluasi pendidikan. Jakarta: Raja Grafindo Persada.

Sudrajat, Akhmad. (2008). Penilaian Hasil Belajar Siswa. http://www.Ahkmadsudrajat. Com (Di akses tanggal 14 Desember 2011)

Sukardi. (2008). Evaluasi Pendidikan. Jakarta: Bumi Aksara

Suryadi. (2010). Pengembangan Pendidikan. Diakses tanggal 23 Februari 2011 dari http://file.upi.edu/

Tayibnapis, Farida Y. (2008). Evaluasi Program dan Instrumen Evaluasi. Jakarta: Rineka Cipta

Yunanda, Martha. (2010). Prinsip dan teknik evaluasi. Diakses tanggal 25 maret 2016 dari http://id.shvoong.com/ 